\title{
Efek Getaran dengan Frekuensi Alami pada Komposit Unsaturated Polyester-Fiberglass Metode Hand Layup terhadap Sifat Mekanik Bending
}

\section{The Effect of Vibration with Natural Frequency to Mechanical Properties Flexural of Unsaturated Polyester - Glassfiber Composites by Hand Layup Method}

\author{
Singgih Prabowo*, Dasep Rusmana \\ Balai Teknologi Polimer - BPPT, Kawasan Puspiptek Serpong Tanggerang Selatan 15314 \\ *Surel: singgih.prabowo@bppt.go.id
}

\section{INFO ARTIKEL Abstract}

Diterima 10 Januari 2019

Direvisi 14 April 2019

Disetujui 20 November 2019

Nomor Artikel 201907

Halaman 7-10

\section{Kata kunci:}

Komposit UPFG

Frekuensi Alami

Hand Layup
One of the causes of material failure is vibration. Vibration is a relative reversible movement to the equilibrium point in a certain interval of time. This study aims to observe the flexural properties of UPFG composite material after being vibrated at its natural frequency over a period of time. Flexural properties were analyzed after being given a vibration treatment for 1, 2 and 3 hours, and compared to without treatment. The results showed that the stiffness and flexural strength of the sample continued to decrease with the duration of the vibration treatment given. After 3 hours of treatment the value of stiffness decreased $20.20 \%$ to 8106,52 MPa, compared to without treatment $10158 \mathrm{MPa}$ and the value of bending strength decreased $15.27 \%$ to $175.36 \mathrm{Mpa}$, compared to without treatment $206.96 \mathrm{MPa}$. Arrangement and bond stability between UP and GF are affected by continuous vibration effect, which reducing the value of stiffness and strength.

Keywords: UPFG composite, natural frequency, hand layup

\begin{abstract}
Abstrak
Salah satu penyebab kegagalan suatu bahan adalah getaran. Getaran adalah gerakan bolak-balik relatif terhadap titik keseimbangan dalam selang waktu tertentu. Penelitian ini bertujuan untuk mengamati sifat mekanik bending material komposit UPFG setelah digetarkan pada frekuensi alaminya selama rentang waktu tertentu. Sifat mekanik bending dianalisis setelah diberikan perlakuan getaran selama 1, 2 dan 3 jam dibandingkan dengan tanpa perlakuan. Hasil penelitian menunjukkan kekakuan dan kekuatan bending sampel terus turun seiring lamanya perlakuan getaran yang diberikan. Setelah perlakuan 3 jam nilai kekakuannya turun sebesar 20,20 \% menjadi 8106,52 MPa dibandingkan dengan tanpa perlakuan $10158 \mathrm{MPa}$ dan nilai kekuatan bending turun 15,27 \% menjadi 175,36 MPa dibandingkan tanpa perlakuan 206,96 MPa. Stabilitas susunan dan ikatan antara UP dan GF terpengaruh dengan getaran yang terusmenerus sehingga menurunkan nilai kekakuan dan kekuatannya.
\end{abstract}




\section{PENDAHULUAN}

Komposit Unsaturated polyester (UP) - fiberglass (FG) merupakan komposit yang paling luas pemanfaatannya karena memiliki harga yang murah, prosesnya mudah, dan memiliki keseimbangan yang baik antara sifat mekanik, elektrik, dan sifat kimianya [1]. Karena keunggulannya komposit UPFG banyak digunakan untuk alat transportasi seperti pesawat, kapal, kereta api dan otomotif bahkan sering juga digunakan untuk struktur bangunan. Ada beberapa macam proses yang telah dilakukan dalam pembuatan komposit, seperti hand layup, vacuum bagging dan vacuum infusion [2-4]. Hand layup merupakan teknik pembuatan yang paling sering digunakan.

Komposit UPFG yang disusun dari beberapa lembaran-lembaran dan menjadi satu kesatuan dengan cara disusun berlapis-lapis diperlukan ikatan yang kuat antara lembaran yang satu dengan yang lainnnya. Ketidaklekatan antar lapisan pada material komposit disebut dengan delaminasi. Delaminasi antar lapisan pada komposit tersebut dapat menyebabkan kerusakan atau kegagalan dan dapat mengurangi modal frequency surface (MFS) dan kekakuan lokal [5]. Salah satu penyebab terjadinya kerusakan struktur akibat delaminasi adalah melalui respon dinamis akibat beban getaran yang merupakan fungsi waktu.

Getaran adalah gerakan bolak-balik relatif terhadap titik keseimbangan dalam selang waktu tertentu. Pada dasarnya semua sistem yang memiliki massa dan kekakuan dapat bergetar. Secara umum getaran dapat dibedakan atas dua, yaitu getaran bebas dan getaran paksa. Getaran bebas terjadi apabila sistem berosilasi setelah diberi simpangan awal atau kecepatan awal dan tidak ada gaya luar yang bekerja. Sedangkan getaran paksa terjadi karena adanya gaya gangguan dari luar. Jika frekuensi getaran dari luar sama dengan frekuensi alaminya maka sistem akan ikut bergetar sesuai dengan frekuensi gangguannya, fenomena ini disebut resonansi [6]. Oleh karena itu penentuan frekuensi alami sangat penting pada suatu sistem yang mengalami getaran [7].

Seiring dengan meningkatnya penggunaan komposit UPFG dan potensi untuk terjadinya getaran dalam penggunaannya, maka akurasi dan efisiensinya terhadap analisis getaran pada suatu struktur sangat diperlukan. dan saat ini belum ada penelitian tentang efek langsung terhadap sifat mekanik bending material komposit akibat getaran pada frekuensi alaminya selama rentang waktu tertentu. Penelitian ini bertujuan untuk melihat efek getaran pada frekuensi alami terhadap komposit UPFG dilihat dari sifat mekanik bending-nya dalam rentang waktu tertentu dibandingkan dengan tanpa adanya getaran.

\section{METODE PERCOBAAN}

\section{Bahan}

Bahan yang digunakan dalam penelitian ini adalah Unsaturated Polyester (Yukalac 150 HRN-EX) sebagai matrik, fiberglass dengan jenis chopped starnd mat (CSM) sebagai filler dan Methyl Ethyl Ketone Peroxide (MEKPO) sebagai inisiator mempercepat waktu curing, semua bahan diproduksi oleh PT. Justus Sakti Raya.

\section{Pembuatan Sampel Komposit}

Proses pembuatan komposit fiberglass dengan metode hand layup di atas flat mold, UP-FG sebanyak 9 lembar dihand layup, dengan perbandingan UP dan serat gelas adalah $1: 2$ lalu didiamkan selama 1 hari. Selanjutnya dilakukan pemotongan spesimen sesuai dengan standar pengujian bending ASTM D790.

\section{Pengujian Komposit}

Uji getaran dilakukan dalam dua tahap yaitu pertama adalah untuk mencari frekuensi alami material dengan scanning frekuensi mulai dari $1 \mathrm{~Hz}$ sampai didapatkan puncak pertama dari grafik amplitudo-frekuensi dengan kecepatan $1 \mathrm{G}$ dan kedua adalah dengan perlakuan getaran terhadap material sesuai dengan frekuensi alaminya dalam rentang waktu tertentu menggunakan alat uji Vibration Test System TIRA model TV 59327/AIT-440 TGT MO 36 XL (Gambar 1).

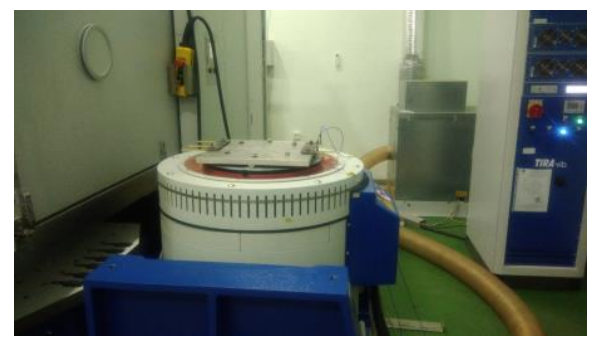

Gambar 1. Pengujian getaran.

Uji bending dilakukan untuk mengetahui kekuatan material terhadap pembebanan tekan menggunakan Universal Testing Machine (UTM) Shimadzu dengan standar yang digunakan adalah ASTM D790 (Gambar 2).

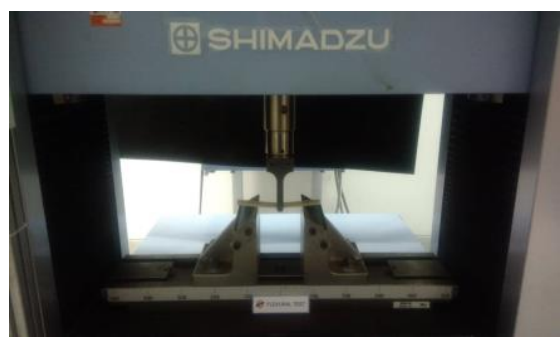

Gambar 2. Pengujian bending. 
Penelitian ini sampel komposit UPFG diletakkan di atas alat ukur getaran dengan dijepit pada satu sisi, sensor diletakkan pada posisi tengah dan digetarkan untuk mencari frekuensi alaminya. Selanjutnya sampel diberi perlakuan getaran pada frekuensi alaminya selama rentang waktu 1 jam, 2 jam dan 3 jam dan dianalisis sifat mekanik bending-nya dibandingkan dengan tanpa perlakuan.

\section{HASIL DAN PEMBAHASAN}

Pada penelitian ini didapatkan frekuensi alami material komposit UPFG adalah $190 \mathrm{~Hz}$ yang ditunjukkan dengan puncak grafik pertama pada Gambar 3. Perlakuan getaran dengan frekuensi $190 \mathrm{~Hz}$ selama rentang waktu 1, 2 dan 3 jam ditunjukkan pada Gambar 4.

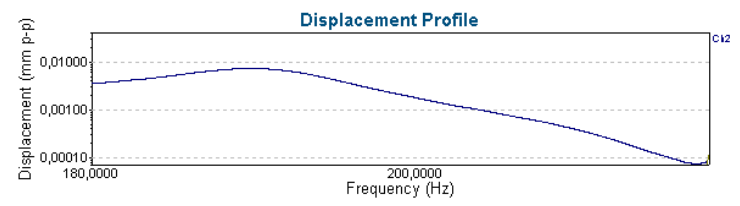

Gambar 3. Grafik penentuan frekunsi alami sampel.
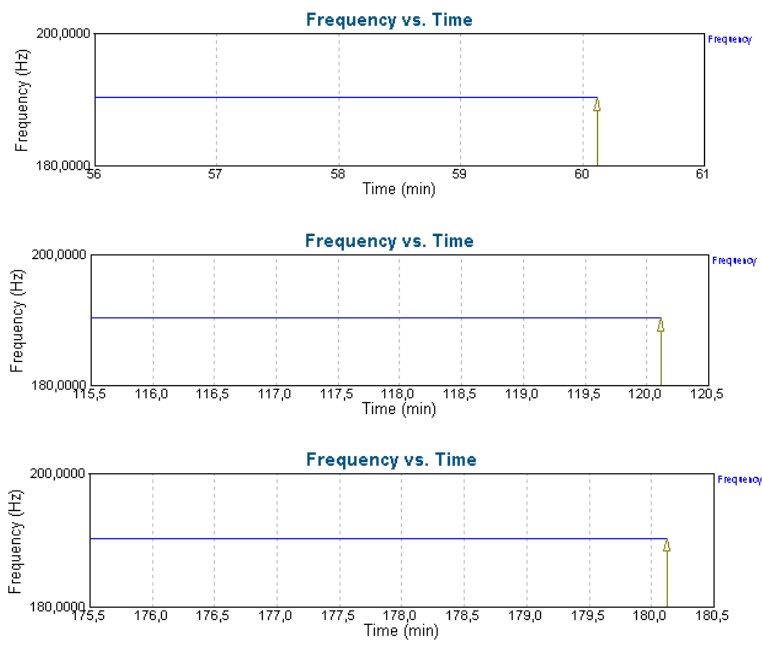

Gambar 4. Grafik uji getar dengan rentang waktu 1, 2 dan 3 jam.

Kekuatan bending menunjukkan penurunan akibat perlakuan getaran yang terlihat pada Tabel 1 . Semakin lama material digetarkan dengan frekuensi alaminya $(190 \mathrm{~Hz})$ nilai kekakuan dan kekuatan bending-nya akan semakin menurun. Dengan perlakuan getaran selama 3 jam nilai kekakuannya 8106,52 $\mathrm{MPa}$, turun sampai 20,20\% dibandingkan tanpa perlakuan getaran sebesar $10158 \mathrm{MPa}$, nilai kekuatan bending-nya 175,36 $\mathrm{MPa}$ turun 15,27 \% dibandingkan tanpa perlakuan 206,96 $\mathrm{MPa}$ dan nilai bending strain terendah pada perlakuan selama 1 jam yaitu 2,28\% turun sebesar 7,69\% dibandingkan tanpa perlakuan. Sedangkan nilai bending strain-nya terendah pada perlakuan 1 jam turun sebesar 2,28\% atau turun $7,69 \%$ dari nilai awal tanpa perlakuan 2.28 $\%$.

Tabel 1. Hasil Pengujian Bending dengan Frekuensi $190 \mathrm{~Hz}$.

\begin{tabular}{ccccc}
\hline No & $\begin{array}{c}\text { Waktu } \\
(\mathrm{Jam})\end{array}$ & $\begin{array}{c}\text { E. Modulus } \\
(\mathrm{GPa})\end{array}$ & $\begin{array}{c}\text { Bending } \\
\text { Strength }(\mathrm{MPa})\end{array}$ & $\begin{array}{c}\text { Bending } \\
\text { Strain }(\%)\end{array}$ \\
\hline 1 & 0 Jam & $10,16 \pm 2,08$ & $206,96 \pm 15,43$ & $2,47 \pm 0,39$ \\
2 & 1 Jam & $9,39 \pm 1,45$ & $189.92 \pm 16,88$ & $2,28 \pm 0,19$ \\
3 & 2 Jam & $9,06 \pm 0,70$ & $181,91 \pm 8,05$ & $2,32 \pm 0,21$ \\
4 & 3 Jam & $8,11 \pm 1,27$ & $175,36 \pm 22,06$ & $2,47 \pm 0,45$ \\
\hline
\end{tabular}
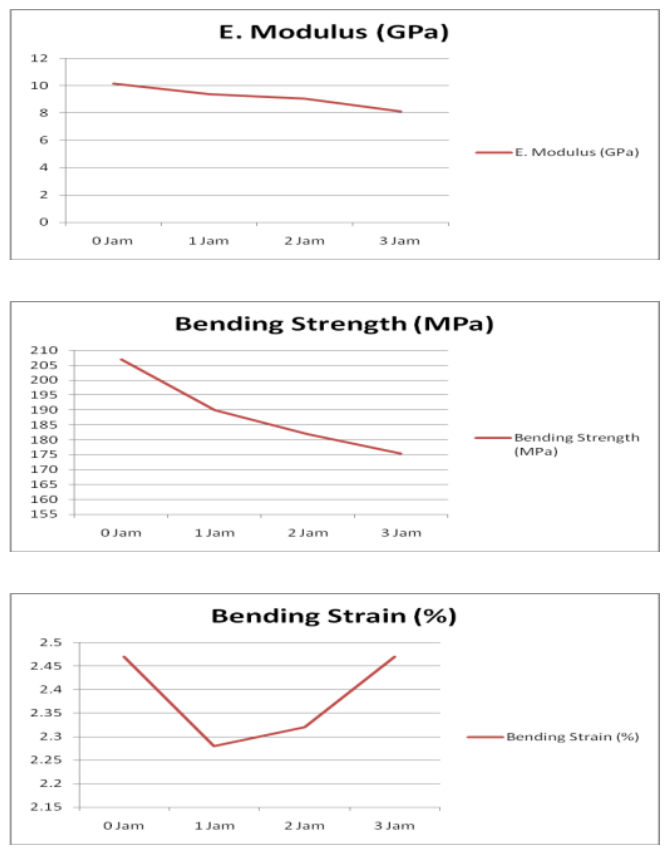

Gambar 5. Grafik E. Modulus, Bending Strength dan Bending Strain akibat perkakuan getaran dalam waktu ktu 1, 2 dan 3 jam.

Dengan perlakuan getaran nilai kekakuan dan kekuatan bending terus menurun signifikan seiring dengan lamanya waktu perlakuan dibandingkan tanpa perlakuan seperti terlihat pada Gambar 5, hal ini kemungkinan terjadi karena ikatan antar layer mengalami pergerakan sehingga menganggu kesetabilan ikatan layer menyebabkan delaminasi yang berakibat menurunkan nilai kekakuannya [5-9], selain itu pergerakan juga mungkin terjadi antara matrik pengikat (UP) dan serat gelas (FG) sehingga berefek pada penurunan nilai kekuatan bending-nya. Sedangkan nilai bending strain walaupun terjadi penurunan tetapi tidak signifikan.

\section{KESIMPULAN}

Efek getaran frekuensi alami pada material komposit berpengaruh sigifikan pada nilai kekakuan dan kekuatan bending-nya dan terus turun seiring lamanya getaran yang diterima material komposit. 


\section{UCAPAN TERIMAKASIH}

Terima kasih kepada rekan-rekan di Balai Teknologi Polimer BPPT yang telah mendukung terselesaikannya tulisan ini.

\section{DAFTAR PUSTAKA}

[1] C.Liu, W.Lei, Z.cai, J.Chen, L.Hu, Y.Dai, Y.Zhou. "Industrial Crops and Products". Use of tung oil as a reactive toughening agent in dicyclopentadiene-terminated unsaturated polyester resins, Vol. 49, pp 412-418, August 2013.

[2] T. Kikuci, T. Koyanagi, H. Hamada, A. Nakai, Y. Takai, A. Goto, Y. Fuji, C. Narita, A. Endo, T. Koshino. "Biomechanics Investigation of Skillful Technician in Hand lay up Fabrication Method". ASME 2012 International Mechanical Engineering Congress and Exposition, 2012, pp $533-539$.

[3] F.Y.C Boey, S.W.Lye. "Composite". Void Reduction in Autoclave Processing of Thermoset Composites. Vol. 23, pp 261 -265, July 1992.

[4] K. van Rijswijk, J.J.E. Teuwen, H.E.N. Bersee, A. Beukers. (2009). "Composite". Textile fiberreinforced anionic polyamide-6 composites. Vol. 40, pp 1-10, January 2009.

[5] Bettinottia, O., Allixb, O., Peregoc, U., Oanceaa, V., Malherbed, B. "Finite Element in Analysis and Design". Simulation Of Delamination Under Impact Using A Global-Local Method In Explicit Dynamics, Vol. 125, pp 1-13, March 2017.

[6] Thomson, W.T. Theory of Vibration with Applications. 4 th Edition. Prentice-Hall, USA. 1998.

[7] Ousset, Y., 1999, "Eur. J. Me\&. A/Solids". Numerical Simulation Of Delamination Growth In Layered Composite Plates, Vol. 18, pp 291 312, 1999.

[8] Yang, C., Oyadiji, S.O. "Computers and Structures", Delamination Detection In Composite Laminate Plates Using 2d Wavelet Analysis Of Modal Frequency Surface, Vol. 179, pp.109- 126, 2016.

[9] I Made Astika. Analisa Delaminasi Pada Glass Fiber Reinforced Polymer Komposit Laminat Dengan Pembebanan Fatigue. Vol. 2, pp 1, January 2012.

[10] ASTM D 790-02, Standard Test Methods for Flexural Properties of Unreinforced and Reinforced Plastic Electrical Insulating Materials, Philadelphia, 2002. 